Mercator, Fortaleza, v. 17, e17019, 2018.

DOI: https://doi.org/10.4215/rm2018.e17019

ISSN: $1984-2201$

Copyright @ 2002, Universidade Federal do Ceará

\title{
BETWEEN RURAL AND THE INNER URBAN AREAS
}

\author{
BEZERRA, Josue Alencar; ${ }^{a *}$ SILVA, Cicero Nilton Moreira ${ }^{b}$
}

(a) Phd in Geography. Professor University of the State of Rio Grande do Norte (UERN), Pau dos Ferros (RN), Brasil. ORCID ID: http://orcid. org/0000-0002-7422-3018. CURRICULUM LATTES: http://lattes.cnpq.br/6018796668587649

(b) Phd in Geography. Professor University of the State of Rio Grande do Norte (UERN), Pau dos Ferros (RN), Brasil. ORCID ID: https://orcid. org/0000-0001-6773-7451. CURRICULUM LATTES: http://lattes.cnpq.br/3089186720597223

\section{(*) CORRESPONDING AUTHOR}

Address: UERN - Campus Universitário, BR-405, km 153. CEP: 59.900-000, Pau dos Ferros (RN), Brasil. Tel: (+55 84) 33512560.

E-mail: josueabezerra@gmail.com

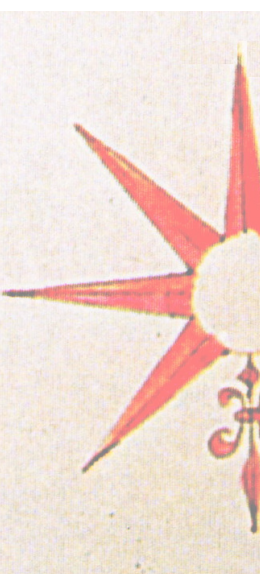

\section{ABSTRACT}

This article aims to discuss regional inequalities, especially in less dynamic spaces, observing the new changes in the territory, which have been evidencing a debate about the countryside-city relationship. In this transitional space (urban-rural), various uses of the territory were observed, such as the emergence of new forms of housing that are confused with spaces with rural features, settled in the vicinity or even alongside small towns. In the process of urban expansion, rural areas are being invaded by the city, giving rise to new spatial arrangements, which do not completely remove the old forms and functions, but provoke a mixture of senses and uses, leading to multiple territorialities. Thus, this paper adopts the role of provoking a theoretical revision about the territorial approach, based on urban and rural spaces.

Keywords: Countryside-city Relationship; Territory; Urban; Rural.

\section{RESUMO / RESUMEN}

\section{ENTRE O RURAL E O URBANO INTERIORIZADO}

Este artigo objetiva discutir as desigualdades regionais, especialmente em espaços menos dinâmicos, observando as novas mudanças no território, as quais vêm evidenciando um debate sobre a relação campo-cidade. Nesse espaço de transição (urbano-rural), observamos diversos usos do território, como o surgimento de novas formas de habitação que se confundem com espaços de traços rurais, assentados nas proximidades ou mesmo ao lado das pequenas cidades. No processo de expansão urbana, as áreas rurais vão sendo invadidas pela cidade - o que origina novos arranjos espaciais, que não destituem totalmente as antigas formas e funções, mas provocam uma mescla de sentidos e usos, e conduzem a múltiplas territorialidades. Dessa forma, este trabalho assume o papel de provocar uma revisão teórica acerca da abordagem territorial, tendo por base os espaços urbano e rural.

Palavras chaves: Relações Campo-cidade; Território; Urbano; Rural.

\section{ENTRE EL RURAL Y EL URBANO INTERIORIZADO}

Este artículo objetiva discutir las desigualdades regionales, especialmente en espacios menos dinámicos, observando los nuevos cambios en el territorio, que vienen evidenciando un debate sobre la relación campo-ciudad. En este espacio de transición (urbano-rural), observamos diversos usos del territorio, como el surgimiento de nuevas formas de vivienda que se confunden con espacios de rasgos rurales, asentados en las proximidades o incluso al lado de las pequeñas ciudades. En el proceso de expansión urbana, las áreas rurales van siendo invadidas por la ciudad - lo que origina nuevos arreglos espaciales, que no destituyen totalmente las antiguas formas y funciones, sino que provocan una mezcla de sentidos y usos, y conduce a múltiples territorialidades. De esta forma, este trabajo asume el papel de provocar una revisión teórica acerca del abordaje territorial, teniendo como base los espacios urbano y rural. De esta forma, este trabajo asume el papel de provocar una revisión teórica acerca del abordaje territorial, teniendo como base los espacios urbano y rural.

Palabras clave: Relaciones Campo-ciudad; Territorio; Urbano; Rural. 


\section{INTRODUCTION}

Geography studies, considered from the perspective of the urban and regional dynamics that select the territory as a category of analysis for research, have favored investigative approaches where the (re) production of capitalism occurs more intensely, such as large cities and metropolitan regions, since such spaces, at the present time, have been shown to be the most latent reflection of the globalization of the economy.

This is a process that allows the debate on the "deregionalization" of the world, due to the relative homogenization promoted by economic and cultural commodification. According to Haesbaert (2010), what is seen is the sharp upsurge of localized regional movements, owing to the very fact that globalization feeds on differentiation and impels it as a need for socio-spatial affirmation.

Taking this framework into account, this study follows the concern of scholars who promote the debate on regional inequalities, especially in less dynamic spaces such as large cities and / or metropolitan regions. On this subject, Santos (2004 [1996]) argues that, as a condition that changes the approach to urban-regional dynamics, contradictorily, spaces can be visualized as a product of the social division of labor, which, through a more dynamic articulation of the needs of capital implementation, reinforce the socio-spatial constraints of selectivity and regional differentiation. On a macroscale, they result from the territorial division of labor, reinforcing preexisting regional inequalities. Hence the importance in this case, of the luminous spaces, more dynamic in relation to the aegis of the great cumulative and financial capital; and the degradation of opaque spaces, which, according to Santos and Silveira (2001), tend to remain on the margins of the main economic flows and present lower levels of income and well-being of the population, measured mainly by the Human Development Index (HDI) and the Gross Domestic Product (GDP) / Inhabitant.

In summary, luminosity reverts to the greater capacity of fixed systems (objects) to respond dynamically to productive demands on a local-global scale; creating and recreating forms and functions, articulated in a structure that reveals the territorial dynamic of the process of flexible accumulation in the contemporary world, as a result of the massive capital flows characteristic of luminosity (SANTOS, 2004 [1996]).

The action of the agents of production of space ends up providing the opportunity to configure multiple territorialities, however, reinforcing the accumulation, inequality and selectivity of the spaces, becoming territories of appropriation and the use of power on a global scale.

Thus, the territory discussed in this article is related to the condition of a used territory, as a theoretical-methodological contribution; as indicated by Schneider \& Tartaruga (2005: 71), an approach "... related to the way of treating phenomena, processes, situations and contexts inherent to a given space (demarcated or delimited by physical, natural, political attributes, or others) where they are produced and transformed. "

The territory, therefore, comes to be used from the perspective of development. It is considered as a variable in intervention policies on space. In this perspective, geography would be faced with the possibility of understanding the production of space. Used territory is " [...] a complex whole where the whole fabric of complementary and conflicting relations is woven. Hence the force of the concept, inviting [one] to think in a processual fashion about the relations established between place, socio-spatial formation and the world" (LABOPLAN, 2000, p.33).

In the Brazilian case, this is evident in the various regional development policies that have resurfaced everywhere to mitigate the negative effects of globalization, such as those implemented by the Ministry of National Integration (MIN, 2005), based on the National Regional Development Plan (PNDR), which proposes strategies to alleviate inequalities within the Brazilian microregions and policies aimed at rural development.

This dynamic has shown, in studying the changes in the Brazilian territory in the last decades, the accelerated occurrence of the process of urbanization, which has considerably modified the 
landscape and daily life of people also living in areas far from the great Brazilian urban centers. However, without forgetting the relative weight of the seats of the small inland municipalities, which are also (re) produced in rural agglomerations of urban extension, ${ }^{1}$ in the format of the regional urban fabric, related to the scale of these municipal units.

To understand this situation, it is important to consider the spatialization of some traditional economic activities, such as livestock and agriculture that still use rudimentary techniques and are quite prevalent in some areas of the national territory. There is also the presence of the so-called new economies, which have been driving the territory in favor of capital.

Among the new economic activities spread throughout the national territory, there is the previously modernized traditional sugar-alcohol complex, which has, however been losing importance to the civil construction and agribusiness sectors - focused especially on the production of grains, tropical fruits, as well as forests for cellulose production (ARAÚJO, 2014). However, the diffusion of the modern tertiary sector has been gaining prominence in small inland municipalities, especially in those that play an important regional role by offering different education, health, and modern commercial services, in addition to specialized business and personal services - as in the case of Pau dos Ferros, circumscribed in the region of Upper West Potiguar, a municipality addressed in Bezerra's thesis (2016), in which he studies the city and the region in an interiorized dimension of the urban network. This fact will be addressed below when focusing on the new countryside-city relationship.

It is understood that in this regard, even in the face of the process of metropolization still present in the country, the diffusion of new centralities within the territory has been verified. For example, by the emergence of medium and small cities, which enabled a remodeling of the territory; characterized by the diffusion of these smaller spaces and, consequently, resulting in new regionalizations, as pointed out in the book organized by Limonad; Haesbaert; Moreira (2004).

These new changes in the territory reveal a costly debate for Geography: the countryside-city relationship. Although there is evidence of increasing generalizations about the homogenization of the territory, there is in fact a certain acceptance on the part of scholars that the cities are constituted from a rural base, that is, they (rural and urban) cannot be analyzed separately.

On this issue, Santos (2005 [1993]) argues that, given the current configuration of urbanization of the territory, it is not possible to distinguish or even separate rural and urban space as if they were isolated and independent realities. We must observe the regional diversities and heterogeneities that involve the aspects of both spaces which, despite having characteristics in common, are transformed from the requirements dictated by the capital in each part of the territory.

In the countryside of the Brazilian Northeast we have observed the insertion of areas where modern agroindustrial activities are not present, where the role of the city and the countryside has gained new traits in the landscape and the socioeconomic dynamics of the place.

So the zone of contact of the countryside with the city, on this scale of analysis, emerges as an object of interest to capital. The so-called peri-urban or rural-urban areas of the cities, in this regional context, are traces of this new configuration of the territory, fomented by the diverse uses of the city and the countryside seen today (RUA, 2006; SOUZA, 2003).

Thus, we carried out a reflexive exercise about the new configurations that the countryside-city interface has been undergoing in time and space. Considering, therefore, readings on the capital and labor relation and the public policies of territorial development and / or land (re)ordering, that remodel urban and rural spaces, under the aegis of the concept of territory and its territorial unfolding in the organization these spaces.

(1) We are using the same name used in the region to identify the small settlements located in the rural area of municipalities. These sites, which we associate with the definition of rural agglomerates (IBGE, 2015), are home to a small number of residents, although, taken as a whole, become representative of the total municipal population. 


\section{TERRITORIAL POLICIES AS PRODUCING MECHANISMS OF THE URBAN-RURAL AREA}

The territorial policies developed, especially in the first decades of the twenty-first century, have shown the inequalities between the Brazilian regions, especially when reporting on the poverty and destitution of the population. According to Plano Brasil Sem Miséria (the Brazil Without Poverty Plan), more than 59\% of the people in this context are in the Northeast region (BRAZIL, 2014). Thus, following the ideas of Santos (2010, p. 126), taking into account the history of the constitution and consolidation of capitalism in Brazil:

Developmental policies operated on the national scale ... once this pattern of accumulation was exhausted, the subnational spaces (local scale) became the territories for the operationalization of policies ... The change of development strategy was presented as a condition for Brazil to adapt to the impositions of the financial markets that seek to establish direct relations with the localities, that become territories of capital appropriation.

Consequently, it is evident that these policies have an urban bias, without paying attention to each territory's specificities, nor its scale and regional insertion. Historically, the State, as well as the companies, emerges as an important agent in the organization of the territory, which involves clashes of power - exercised by different agents, giving the territory a reflection of the relations of power (RAFFESTIN, 1993).

Another noteworthy issue in this regard is the lack of transparency in public policies in various governmental spheres (federal, state and municipal) in reading smaller spaces that are farther away from the great Brazilian centers. Here, we highlight the small municipalities, whose seats ${ }^{2}$ often do not even have urban features; within these small municipalities the population lives in the countryside, outside of the country's major agro-industrial centers.

But, what public policies are we talking about? Melazzo (2006: 36) points out that public policies geared to territorial development include:

[...] sets of decisions and actions aimed at solving political problems, involving formal, informal and technical procedures that express power relations and which are aimed at resolving conflicts over the rights of groups and social segments or as space where different conceptions regarding the formulation and implementation of social rights, as well as their extension to different social groups, are disputed.

From what we have observed in recent years, these policies are absent from a plan that considers the diversities and heterogeneities of the territory, added to the absence of integration among the agents involved in this process. Especially, when more deeply impacting actions run up against the structural and personnel limits in municipal public power (local agents).

Territorial development policies in areas with a fragile socioeconomic profile are more common than is imagined. They are frequent in the interior of the Brazilian Northeast, as evidenced in the National Program of Sustainable Development of the Rural Territories (PRONAT) and the largest housing program in the country today, "Minha Casa, Minha Vida" (My house, my life) launched in 2003 and 2009, respectively.

These programs have caused changes in the environment of the small municipalities of the northeastern countryside. Many of them are located in areas devoid of economic activities that support a full and self-sustaining development of the social and economic structures of the local population.

(2) Davidovich and Geiger (1961) discussed the official criteria established by several countries to define what a city would be and in Brazil, the choice of political and administrative criteria stands out. Thus, here "The seat of the municipality has the category of city and gives itsname," as established in Decree-Law number 311, March 1938, in its third article (BRAZIL, 2015 [1938]). 
It is common knowledge that many of these municipalities survive on government transfers, basically carried out through public transfers, which are the core of the dynamism of their local economies. These transfers are mainly made through the following channels: Municipal Participation Fund (FPM) and transfers to education, through the Fund for Maintenance and Development of Basic Education and Valorization of Education Professionals (FUNDEB) and the Unified Health System (SUS) ), social programs (mainly Bolsa Familia), rural pensions from the National Institute of Social Security (INSS), as well as the salaries of federal, state and municipal civil servants, which reinforce this situation in general.

The search for strategies that allow an approximation between the different agents involved, especially at the local level, either with popular or external agents, ${ }^{3}$ could be the one that prioritizes the projects that contemplate the territory as a whole, with a view to the development in their different aspects and scales.

In the municipal dimension, the Master Plan is an important instrument of territorial planning instituted under the City Statute (BRASIL, 2001), whose main objective is to facilitate the democratic participation of the population in the discussions on the inclusion of instruments that guarantee the social function of land ownership and occupation, for example. However, in Brazil, until the year 2013, 50\% (2,785) of the municipalities did not have a Master Plan, ${ }^{4}$ with the Midwest $(40.4 \%)$ and Northeast (40.7\%) having the lowest index of this kind of planning (IBGE, 2014). These facts are considered to be obstacles in the application of the political actions undertaken by the State, thus contributing to the fragility of the structure and planning of the public power. This is a political-ideological limit that insinuates itself precisely into the clear perception that, beyond integrating institutions, there is a need to instrumentalize the most vulnerable social subjects.

In the context of small cities, a decrease was observed in the structures and spatial dynamics in which some public policies, geared towards territorial development, were implemented; with the main focus being on easing regional inequalities. For this purpose, there are housing policies, notably the "My House, My Life" Program (Minha Casa, Minha Vida Program). This is one of the main policies that have promoted changes in the social and economic order of the population, other space producing agents (SPOSITO, 2011); both those who live in the peripheries of the great centers and inhabitants of the small cities of the countryside of the Northeast. Bezerra's (2016) thesis evidences that a considerable part of the socio-territorial impacts (real estate speculation, the land market boom, the incorporation of rural land into urban, urban expansion and changes in land use and occupation, among others) have been provoked by this policy.

\section{BETWEEN THE RURAL AND THE URBAN: THE USES AND COEXISTENCE OF TERRITORY}

The occurrence of temporal simultaneities and the coexistence of structures over space can be seen on various territorial scales, although the forms of coexistence of multitemporalities are not as clear and diverse, Haesbaert (2004). The large city exemplifies that today there is the affirmation of the moment of recreation (cultural centers, artistic spaces and patrimonial revaluation, which give an idea of going back in time) that therefore generate the possibility of understanding multitemporality, from the use of places and their marks on space and, consequently, the identification of their rugosity. Regarding this aspect, Santos (2008 [1978], 173) writes that "The rugosity of space is built space, historical time that has become landscape, incorporated into space." 5

Within this context, the concepts of rural and urban - the forms of expression of human life in

(3) An interesting reading about the levels, scales, and techniques of popular work is Boff (1986).

(4) According to the City Statute (BRASIL, 2001), the Municipal Master Plan is the basic instrument of urban territorial planning, and should define the use and occupation characteristics of each portion of the municipal territory, creating all their social function.

(5) Santos (2004, p. 140) still posits that rugosity is what "[...] is left of the past as form, built space, landscape; what remains of the process of suppression, accumulation, superposition, with which things are replaced and accumulated everywhere. " 
society, and fruit of the action of historical subjects through labor, in order to produce space - are now the subject of queries about their understanding.

Therefore, this could be called another form of expression of the dual vision of development in society today: the "false" impression of the rural-urban dichotomy, based on the unequal configuration of capitalist society.

In a dual perspective, from the point of view of traditional analysis in the studies of Urban and Regional Geography such a dichotomy generally assumes the application of the concepts that separate them into "two worlds", requiring different treatments.

It is the composition of two worlds in conflict, counterpoised and in a permanent struggle for supremacy or pre-eminence. In practice, this has led to the application of differentiated strategies to the rural and urban universes. According to English (2006), the definitions that separate these two spaces-universes, in the set of theoretical-methodological constructions formulated, end up determining political and institutional treatments, resources and political discourses based on an idea of deep separation. They end up fomenting State intervention or the action of different political institutions, economic agents and social organizations.

Other interpretive readings, based on the theoretical effort on the relationships and contradictions between rural and urban, can also be obtained in Bali (2006), who bases his approach on the vision between the "harmonious" and "conflict", in the cadence of the contradiction that underlies the countryside-city relationship; as well as the reading of Rosa and Ferreira (2006), which reveal the rural and urban, countryside and city categories in the perspective of an analysis around a continuum, that is, being configured in a multidimensional and non-linear reading on the relationships that engender the territory and its territorialities, coming from the perspective of the appropriation and use of space.

In this interpretative field, spaces and territories are integral, and have characteristics such as: demographic density structures, economic sectoriality and landscape conformation that complement each other. The countryside and the city, according to this theoretical understanding, would form an "indissoluble unity" in operation and functions and conform their articulations through their networks and flows. Therefore, the State should seek to read and exercise an understanding of these qualities, and then construct proposals for intervention and political action.

Within this context, for geographic reflection, in times of economic globalization and the intensification of inequalities under the yoke of offensive capitalist rationality, how one can (re) think the countryside-city relationship in this scenario, considering the Brazilian reality? Without presuming to account for the depths that surround this question, the reflexive challenge on the countryside-city problem is posed .

When analyzing what she calls "agricultural areas of exclusion", Elias (2006) considers that the diffusion of agribusiness takes place in an extremely exclusive way, contributing to the accentuation of historical social and territorial inequalities.

In fact, the conservative modernization in the countryside, ${ }^{6}$ which started in a more emphatic way in the $1960 \mathrm{~s}$, contributed in a salutary manner towards maintaining the concentration of power and wealth in the hands of the privileged few: landowners and rural entrepreneurs.

The reading of the Brazilian rural world in the period, in a sense, was that of "development" for a few and delay for many. Inequality in the countryside and increasing environmental degradation are the striking impacts of this perspective.

(6) The term conservative modernization was first coined by Moore Junior (1975), as he studied bourgeois revolutions in Germany and Japan, with the transition from preindustrial economies to capitalist and industrial economies. According to Silva (1997), in Brazil there was a conversational modernization characterized by the transformations of the technical basis of agriculture, which preserved the concentrated and excusionary land structure. 
The semi-arid Northeastern region, which, according to this discussion, has frequent droughts as its main feature, characterized by the absence, scarcity or high spatial and temporal variability of rainfall, is a region that undoubtedly serves as a reference for the analysis of regional development policies.

The characteristics of the environment, in this region, strongly condition the regional society to survive in an often precarious way of life, mainly from economic activities basically linked to agriculture and livestock. However, the population, historically pauperized by the secular tradition of coronelismo and political patronage, as Oliveira (1981) and Bursztyn (1984) argue, even with unfavorable natural conditions, relies on a fragile technical base and, in most cases, on the use of traditional technologies. An exception are the "archipelagos of prosperity", destined to export production - the so-called agribusiness of the 1990s - spaces of productive restructuring, as defined by Elias (2003).

In contradiction, there is considerable investment by the state and large landowners in the application of modern technologies. However, they are limited to the restricted "archipelagos of prosperity". In the state of Ceará, especially in the valleys of the Jaguaribe and Acaraú rivers, or, for example, in the Açu-Mossoró ( $\mathrm{RN}$ ) valleys; valley of the São Francisco river between Petrolina (PE) and Juazeiro (BA).

In the complex world of modern business, where agribusiness is embedded, this process is known as reengineering, or restructuring of productive forces, to better manage activities related to production, circulation, distribution and consumption - in the search of greater agility, productivity and profitability, following the path of the logic of flexible capital accumulation, and it is the fragile areas that reflect this inequality the most, although there is also an interest in them on the part of big capital.

\section{THE TENUOUS DIMENSIONS OF THE URBAN-RURAL}

The process of expropriation or even the social uprooting of populations living in areas away from large economic activities and the more complex urban environment does not seem to be linked just to social choices and preferences. Historically, societies seek development and believe they see it when linkages with the place are provided.

The demands that capital presents are decisive for the real uses of the territory, whatever the scale being considered. The specificities of this portion of analysis will come to light when the ways in which capital acts are identified: in the forms of housing, in the skills and / or vocation of the place for a particular economic activity, among others. Thus, specific characteristics of the territorial division of labor were verified in the smallest territorial units, either in parts of the city or in rural agglomerations of urban expansion. ${ }^{7}$

Often, public development policies become the main instruments responsible for the structural and socioeconomic dynamics of these spaces, dictating the current conformation of the territory, including those areas where hegemonic capital companies are not physically present, in the Brazilian regional periphery - comprised of smaller municipalities, located especially within the regions and away from large urban agglomerations. From the studies that we carried out in a regional reality inserted in the semi-arid northeastern region, ${ }^{8}$ the need was felt for a new reading of some changes observed in the countryside-city dimension in this scale of the territory.

(7) According to IBGE (2015, p.36), a rural agglomeration of urban expansion is a "Locality that has the defining characteristics of rural agglomerate and is located less than $1 \mathrm{~km}$ away from the urban area of a town or village.

(8) We are referring to Bezerra's thesis (2016) and the recent text that we published in the book "Territory: way of using and thinking" (SILVA; BEZERRA, 2016), the result of institutionalized research carried out within the scope of the Agrarian Geography Studies Center and Regional (NuGAR) of the Campus of Pau dos Ferros of UERN. 
By choosing the smallest unit in the territory of a political-administrative organization, officially recognized in Brazil, the small municipality, whose headquarters (small towns), as well as rural clusters of urban extension or even isolated locations, have undergone great social and economic transformations, we are compelled to make a particular reading of the territory.

Thus, when considering the Northeastern case, we are faced with a situation that contrasts with a historical relationship with natural adversities, specifically linked to the semi-arid climate, which in the beginning contributed to the slowing down of the occupation of its territory, although, at the same time it is a less populated area than the coast, currently one of the densest, demographically, in the world (SALES, 2002).

In the region's interior there is a reality composed of small municipalities that are in full mutation and which shelter public services, commerce, capital, information, transportation, among other services aimed at meeting the most immediate needs of the local population.

In this transitional space (urban-rural) several uses of the territory have been observed, such as the emergence of new forms of housing, some of popular character that are mixed with spaces of rural features, established in the vicinity or even beside these small cities of the Northeast.

Often it is not possible to identify these areas as urban or rural spaces in the municipalities, but, as was stated above, they are close to the periphery, a legal and administrative limit of the city, and therefore, unfavorably located in relation to the offer of goods and services.

The location of these social groups in the vicinity of the city is dictated by the needs of the agents producing the urban space, especially by landowners, the owners of the means of production and of the State itself (SPOSITO, 2011). These areas are subject to the possibilities of increasing the extraction of urban land income, which allows, among other things, the accentuation of the segregation in the territory.

Although there is no precise data on the socioeconomic profile of these groups living in these countryside areas of the Northeast, in general, it can be verified that they are composed of workers and consumers of space that begin to take on social practices characteristic of urban life, such as the use of modern equipment and services: washing machine, microwave oven, cable TV, broadband internet, beauty and leisure services in general, among others. Thus, the choice of the best location for the use of the territory, whatever its end, is not conditioned to its rationality, but to efficiency from the point of view of capital, as Calabi and Indovina (1992) point out.

It should be noted that, even with the credit facilities offered in recent years, which have made it easier to buy a home, for example, paradoxically, with urban unemployment increasing and with increasing transport, it was noted that there is a preference on the part of these people to stay in these areas bordering the cities, in the rural area or even in neighboring municipalities.

Silva (1997) had already warned that these rural agglomerations, located close to the urban centers of these small municipalities, now emerge as a reservoir of unemployed populations and a shelter for large numbers of retirees - which also denotes a break in the relationship between the places of residence and work of these people.

This circumstance enabled a reconfiguration in these areas of these small municipalities of the Northeast, especially those that play a polarizing role in the activities and structures of a region, and are, safeguarding the propositions, conforming to spatial practices similar to those observed in some large Brazilian centers.

In general, the areas surrounding cities undergo intense and diversified land use processes, mainly due to the proximity of the urban nucleus, real estate speculation and local policies that favor urban activities to the detriment of rural ones, in the words of Moura and Conceição (2010). In this way, urban space and its supremacy, as the center of capital accumulation, incorporates a diversity of productive processes, in addition to various forms of work.

In the urban fringes of the cities that, in an earlier period, were characterized by eminently agricultural activities, urban and rural activities have been combined, carried out by those excluded 
from formal urban work, who, as a survival strategy, continued to develop traditional activities of precarious character, but which remain necessary in the contradictory logic of capitalist accumulation, still in the assertion of Moura and Conceição (2010).

Thus, space is transformed not only by reason of relatively continuous global processes, but it takes on the character of transformations in countryside-city relationships, in class relations, and in the property regime. However, such configurations can be understood as initiatives that amplify rural and urban plots, which are commonly analyzed in a conservative view, in a dissociated and / or almost insurmountable way. An example of this is the practice of urban and peri-urban agriculture, in its different scales: domestic gardens, communal and collective vegetable gardens, and peri-urban areas of family agriculture; as well as the new circuits of production and consumption that activate, in different configurations, the connections between the countryside and the city, as Prado (2015) puts it.

In the process of urban expansion, rural areas are being invaded by the city - which gives rise to new spatial arrangements, which do not completely dismiss the old forms and functions, but cause a mixture of meanings and uses, leading to multiple territorialities, preserving "non-capitalist" relations of production, though completely embedded in the logic of accumulation. According to Moura and Conceição (2010: 152), in the application of public policies, in general, "these spaces are being constructed and rebuilt, generating discontinuities and groupings without considering preexisting economic and social relationships $[\ldots]$ ". Thus, we can point to the formation of a fragmented urban space where contradictions are formed and questions raised that redefine the traditional country-city relationships.

From this perspective, institutionalized initiatives in public policies, such as governmental purchases of products from family agriculture by public schools, through the National School Food Program (PNAE), for example, end up being translated into formal and informal, individual or collective initiatives, by groups of urban consumers, chefs and activists that reach a new level: the consumption of fresh and healthy food, now under the discourse of agroecological production. According to Prado (2015, pages 6 and 7, our emphasis), from:

[...] this diverse set of practices and concrete experiences new food geographies are emerging that have as important axes of operation the reconfiguration of the relations between the market and civil society in the conformation of short agri-food circuits; new relationships between the public sector, as a consumer, and the market; and the demand for legal landmarks that recognize spaces of production and new perceptions about rural and urban.

In this way, it is evident that a vast field of research and intervention has been opened up, questioning how alternative agrifood networks are formed and how they are established over time and space, the types of markets they cover and the effect of practices which derive from the places where they occur, insofar as they go beyond rural areas.

We would therefore be dealing with a set of initiatives that, driven by different agents in various spheres of action, have contributed in practice to a new reading of the configuration of the relationships between urban and rural spaces, through agriculture and food. In this manner, these elements end up (re) configuring the countryside-city relationship. Redefining them, from multiple territorialities, or contributing to the affirmation of other readings of possible territorialities between rural-urban, such as peri-urban and / or rural areas.

Understanding this process means considering the city, periurban space and rural space as elements of a single system, according to the research of the authors Moura and Conceição (ibidem), mentioned above. Thus, peri-urban space only has validity as long as it is considered in the interactional set, in which it is (re) produced in relation to the city and the countryside. In this context, the transformations arising from the economic, social and political processes that are present in contemporary urbanization end up exerting an influence on this new configuration, which we 
call urban.

It is important to stress, however, that the strong urbanization process in Brazil, while representing the taking of rural areas as a the center of disputes over power, for example, did not necessarily mean the complete renunciation of the rural population of the activities and to the customs of the countryside, which are (still) produced today across the countryside of Brazilian cities. This construction allowed the emergence of subspaces (periurban spaces, or even spaces of conformation of the rurbanities).

In this sense, the transitional character and physiognomy of the Irrigated Perimeter of Pau dos Ferros (RN), which characterizes it as a space that is transformed in the interaction between the intervention caused by the relations between the social subjects that (re) produce it. It can be understood within this analytic-interpretative perception, that is, based on the identification and investigation of periurban space.

This is a characteristic that is noteworthy, particularly in the northeastern countyside, because they appear as extension of the main city. However, on the one hand they present themselves as an urban economy linked to rural activities, or they are essentially embedded in tertiary activities.

These spaces present morphological and functional characteristics that are very different from the larger cities and cannot be distinguished from the characteristics of a village that is usually located on a roadside, and which differs little from the pericentral zone, with a sudden transition to rural area.

These spaces appear as appendices of the city, and have shown us traces of this tensionality between the rural and urban in the territory. As an example of this process, we have the expansion of higher education institutions and technological schools into the countryside, which has created possibilities for the new (urban) society to reach these new needs, valuing research that presents itself as the best alternative to agricultural activity; on the whole, this is traditionally based on rain-fed agriculture, practically unsustainable in the region. Thus, in counterpoint, the new values are acquired / sought, present in the everyday of the urban middle class. Their intentions of inserting themselves once and for all in urban life point to a certain incompatibility with the intention of remaining isolated from the city.

In these areas, which we continue to call periurban, in addition to housing, the materialization of the urban is taking place, fulfilling some needs that until recently were not that important, such as the beauty salon; which was formerly only frequented at the end of the year or for the popular festivals; the bakery; the grocery store, which have already been updated with the new modern purchasing practices (credit card, home delivery, communication and information via cyber cafes etc., as well as the practice of associativism); churches of various religious practices, among others.

These spaces are a tenuous representation of rural and urban in the northeastern countryside; close to the main square and / or main street and, consequently, services and trade which so far cannot be found in a agglomerated and complex way.

Thus, we could infer that the countryside marks the city through agricultural activities present in the periurban or rurban space, however, this mark is configured both by the need for survival, and by the desire to (re) be constituted through the daily affirmation of these practices in society.

\section{FINAL CONSIDERATIONS}

In general terms, it can be stated that the Brazilian State has acted, throughout the history of urban-regional development policies, as the mediator of the practices of fomentation of the modernization of the productive sectors of the economy, with rebuttals in the configuration of the space, becoming a territory from the uses of the space-producing agents, enabling re-readings of the countryside-city relationship.

This brings us to the challenge of seeking a reflective deepening of the convergences and 
divergences between theoretical and methodological matrices based on a (re) reading of this relationship, considering the understanding of how the public policies for rural territorial development have been conceived, in the last two decades a priority, as well as the new urban territorialities in contemporary Brazil.

The so-called "new urban-regional configurations" also point to other motivations for a geographical reading of development. These, being configured as challenges to the territorial approach, in the face of the unequal character of the geographical development, thought and applied, conceived and lived. This investigative approach is based on the need to foster, together with scholars of the human and social sciences, especially geographers, the key-point of "Dialectical Utopism" (HARVEY, 2004). In other words, it seems to point to the need for a (re) construction of the ideals of the intellectual being in times of globalization: the architect's affirmation of new readings, understandings and (re) constructing other possible paths for modern society.

In this sense the proposal of this paper, takes on the role of providing reflection on the theoretical elements that support the (multi) territoriality reading, between urban and rural spaces. And, in particular, another possible view, based on the perspective of the assertion of so-called rurbanities in peri-urban spaces. That is, spaces become territories of the action of the social subjects that (re) construct them, in the middle of the materialistic appropriation and / or through the territorial identity.

The problem posed regarding the new relationships in the territory, especially considering the investigation of urban and rural internalized, warn Geography about the challenge of the conceptual (de) construction of the territory and its contemporary outcomes. In view of this theoretical debate on the above mentioned issues, it is hoped to contribute to the discussion of socio-spatial processes that engender the conception and practice of public policies of the State, around the development of productive forces. This research position points to the configuration of the territory used, as a bias of interpretative analysis of these realities, represented in the reading of the "new" countryside-city relations, which permits the verification of (multi) territorial modifications related to the dynamics of rural-urban dimensions in contemporary times.

\section{BIBLIOGRAPHIC REFERENCE}

ARAÚJO, Tânia Bacelar. Nordeste: desenvolvimento recente e perspectivas. Caderno 19. In: GUIMARÃES, Paulo Ferraz; AGUIAR, Rodrigo Almeida de; MARTINS, Helena Maria; SILVA, Lastres Marcelo Machado da. Um olhar territorial para o desenvolvimento. Rio de Janeiro: BNDES, p. 539-560, 2014.

BAGLI, Priscila. Rural e urbano: harmonia e conflito na cadência da contradição. In: SPOSITO, Maria Encarnação Beltrão \& WHITACKER, Arthur Magon (Orgs). Cidade e campo. São Paulo: Expressão Popular, p. 81-109, 2006.

BEZERRA, Josué Alencar. A cidade e região de Pau dos Ferros. 429 f. Tese (Doutorado em Geografia). Universidade Estadual do Ceará, Centro de Ciências e Tecnologia, Programa de Pós-graduação em Geografia, Fortaleza, 2016.

BOFF, Clodovis. Como trabalhar com o povo. Rio de Janeiro: Vozes, 1986.

BRASIL. Estatuto da Cidade: Lei no 10.257/2001 que estabelece diretrizes gerais da política urbana. Brasília, Câmara dos Deputados, 2001.

BRASIL. Plano Brasil sem miséria. Disponível em: http://aplicacoes.mds.gov.br/sagirmps/ferramentas/ nucleo/grupo.php?id_grupo=78. Acesso em: 10 nov. 2014.

BRASIL. Dispõe sobre a divisão territorial do país. Decreto-Lei n. 311, de 2 de março de 1938 (Publicação Original). Edição Federal. Disponível em: http://www2.camara.leg.br/legin/fed/de-clei/1930-1939/decreto-lei-311-2-marco-1938-351501-publica-caooriginal-1-pe.html. Acesso em: ago. 2015 [1938].

BURSZTYN, Marcel. O poder dos donos. Petrópolis: Vozes, 1984.

CALABI, Donatella; INDOVINA, Francesco. Sobre usos capitalistas do território. Orientação, São Paulo, n. 9, p. 37-66, 1992. 
DAVIDOVICH, Fany Rachel; GEIGER, Pedro Pinchas. Aspectos do fato urbano no Brasil. Revista Brasileira de Geografia, a., 23, n. 2, Rio de Janeiro, abr./jun. 1961.

ELIAS, Denise. Desigualdade e pobreza no espaço agrário cearense. Mercator, a. 2, n. 3, 2003. p.61-69.

ELIAS, Denise. Ensaios sobre os espaços agrícolas de exclusão. Revista NERA, Presidente Prudente. a. 9, n. 8, Jan./Jun., 2006. p. 29-51.

ENDLICH, Ângela Maria. Perspectivas sobre o urbano e o rural. In: SPOSITO, Maria Encarnação Beltrão; WHITACKER, Arthur Magon (Orgs.). Cidade e campo. São Paulo: Expressão Popular, 2006, p. 11-31.

HAESBAERT, Rogério. Territórios alternativos. Niterói/São Paulo: EDUFF/Contexto, 2004.

HAESBAERT, Rogério. Regional-global. Rio de Janeiro: Bertrand Brasil, 2010.

HARVEY, David. Espaços de Esperança. São Paulo: Edições Loyola, 2004.

IBGE - Instituto Brasileiro de Geografia e Estatística. Perfil dos municípios brasileiros 2013. Perfil de informações básicas municipais. Rio de Janeiro, 2014.

IBGE - Instituto Brasileiro de Geografia e Estatística. Glossário dos termos genéricos dos nomes geográficos utilizado no mapeamento sistemático do Brasil. v. 2. Rio de Janeiro, 2015.

LABOPLAN (Et al). O espaço geográfico e o território usado. São Paulo: Laboplan, 2000.

LIMONAD, E.; HAESBAERT; R.; MOREIRA, R. (Orgs.). Brasil. São Paulo: Max Limonad, 2004.

MELAZZO, Everaldo Santos. Padrões de desigualdades em cidades paulistas de porte médio. A agenda das políticas públicas em disputa. $230 \mathrm{f}$. Tese (Doutorado em Geografia). Universidade Estadual Paulista, Faculdade de Ciências e Tecnologia. Presidente Prudente, 2006.

MIN - Ministério da Integração Nacional. Política Nacional de Desenvolvimento Regional (sumário executivo). Secretaria de Programas Regionais. Brasília: SPR, 2005.

MOURA, Marcleia Elias; CONCEIÇÃO, Alexandrina Luz. A metamorfose da terra rural em solo urbano: a relação campo-cidade no movimento contraditório capital x trabalho. In: SOUZA, Suzane Tosta; SANTOS, Jânio Roberto Diniz dos (Orgs). Leituras sobre a relação estado-capital-trabalho e as políticas de reordenamentos territoriais, Vitória da Conquista: Edições UESB, 2010.

MOORE JUNIOR, B. As origens sociais da ditadura e da democracia. São Paulo: Martins Fontes, 1975. OLIVEIRA, Francisco de. Elegia para uma nova re(li)gião. Rio de Janeiro: Paz e Terra, 1981.

PRADO, Bruno Azevedo. Novas conexões entre o rural e o urbano. Agriculturas, v. 12, n. 2, junho, 2015. RAFFESTIN, Claude. Por uma geografia do poder. São Paulo: Ática, 1993.

ROSA, Lucelina Rosseti; FERREIRA, Darlene Aparecida de Oliveira. As categorias rural, urbano, campo, cidade: a perspectiva de um continuum. In: SPOSITO, Maria Encarnação Beltrão \& WHITACKER, Arthur Magon (Orgs.). Cidade e campo. São Paulo: Expressão Popular, 2006.

RUA, João. Urbanidades no rural. Campo-Território, Uberlândia, v. 1, n. 1, fev. p. 82-106, 2006.

SALES, M. C. Linhares. Evolução dos estudos de desertificação no Nordeste Brasileiro. GeoUSP, n. 11. p. 115-126. São Paulo, 2002.

SANTOS, Ana Rocha dos. A descentralização e (des)envolvimento local: o município na centralidade da gestão do território. In: SOUZA, Suzane Tosta; SANTOS, Jânio Roberto Diniz dos (Orgs). Leituras sobre a relação estado-capital-trabalho e as políticas de reordenamentos territoriais. Vitória da Conquista: Edições UESB, 2010.

SANTOS, M. O papel ativo da geografia. Revista Território, Rio de Janeiro, ano V, n. 9, p. 103-109, jul./ dez., 2000.

SANTOS, Milton. A natureza do espaço. 4. ed. EDUSP: São Paulo, 2004 [1996].

SANTOS, Milton. A urbanização brasileira. 5. ed. EDUSP: São Paulo, 2005 [1993].

SANTOS, Milton. Por uma geografia nova. 6, ed. EDUSP: São Paulo, 2008 [1978].

SANTOS, Milton; SILVEIRA, Maria Laura. Brasil. Rio de Janeiro: Record, 2001.

SCHNEIDER, Sérgio; TARTARUGA, Iván G. Do território geográfico à abordagem territorial do desenvolvimento rural. In: Primeiras Jornadas de Intercâmbio y Discusión. Trabajos. Buenos Aires: CONICET, 2005. SILVA, Cícero Nilton Moreira da; BEZERRA, Josué Alencar. Desenvolvimento e território: usos e coe- 
xistências entre o rural e o urbano interiorizado. In: SILVA, José Borzacchiello da; SILVA, Cícero Nilton Moreira da; DANTAS, Eustógio Wanderley Correia. Território. Fortaleza: Edições UFC, 2016.

SILVA, José Graziano da. O novo rural brasileiro. Nova Economia. v. 7, n. 1, p. 43-81, 1997.

SOUZA, Marcelo Lopes de. ABC do desenvolvimento urbano. Rio de Janeiro: Bertrand Brasil, 2003.

SPOSITO, Maria Encarnação Beltrão. A produção do espaço urbano. In: CARLOS, Ana Fani Alessandri; SOUZA, Marcelo Lopes de; SPOSITO, Maria Encarnação Beltrão. A produção do espaço urbano. São Paulo: Contexto, 2011, p.123-145. 